\title{
Breeding Cold-hardy Fruit Crops in Minnesota
}

\author{
J.J. Luby \\ Department of Horticultural Science, University of Minnesota, St. Paul, MN 55108
}

The Univ. of Minnesota has one of the oldest, continuous fruit breeding programs in North America. It serves a region that experiences all the vagaries of a continental climate, with temperatures ranging from above $35 \mathrm{C}$ in the summer to below $-40 \mathrm{C}$ in the winter. Precipitation, as rain during the growing season and snow during the dormant season, can vary dramatically from year to year. These would not seem to be the most ideal conditions for fruit growing. Indeed, as newspaperman Horace Greeley reportedly said in 1860, "I would not live in Minnesota because you can't grow apples there. "The goal of the breeding program is to develop fruit cultivars that will survive and bear fruit regularly at a commercially profitable level under these conditions. The success of the program is due to a) long-term continuity of dedicated researchers and financial support for the breeding effort, $b$ ) the capability to evaluate genotypes for cold hardiness in laboratory freezing trials and in multiple-location field trials during advanced testing, and c) the collection, evaluation, and use of key cold-hardy germplasm.

\section{HISTORY OF THE PROGRAM AND PRESENT ACTIVITIES}

The origin of fruit improvement in Minnesota can be traced back to 1865 when $\approx 150$ apple cultivars were obtained from Russia for testing (Snyder, 1983). Some of this material became the base for initial apple breeding efforts. Settlers in Minnesota were discouraged by the dearth of fruits that could be grown in the new state. The Minnesota State Horticultural Society lobbied the legislature to provide funds for a fruit breeding effort. In 1878, the Minnesota legislature appropriated $\$ 2000$ for land acquisition and $\$ 1000$ in annual operating expenses for an experimental farm at Excelsior. Peter Gideon, originator of the widely grown 'Wealthy' apple, was named superintendent. This first farm was sold in 1907, and in 1908 the proceeds were used to purchase new property south of Excelsior. This farm became known as the Fruit Breeding Farm and, today, as the Univ. of Minnesota Horticultural Research Center (Alderman, 1976).

Several individuals had key roles in providing continuity to fruit

Scientific Journal Series no. 16,904 of the Minnesota Agricultural Experiment Station. I thank D. Bedford, P. Hemstad, S.T. Munson, D. Wildung, K. Sargent, W. Gray, E. Hoover, G. Galletta, and C. Finn for their comments on this manuscript and their invaluable contributions to the Univ. of Minnesota fruit breeding program in recent years. breeding at the university. S.B. Greene began crossing apples in 1888 as the first head of the Dept. of Horticulture at the university. Charles Haralson was the first superintendent (1908-23) of the Fruit Breeding Farm. The 'Haralson' apple, the most widely grown cultivar in the state, bears his name. Important individuals who followed him included M.J. Dorsey (1908-21), W.H. Alder-man (191953), A.N. Wilcox (1923-63), and C. Stushnoff (1967-80). The efforts of these scientists and their coworkers have led to the introduction of some 80 cultivars of various fruits (Table 1) to enhance fruit growing in this harsh continental climate. Some are widely grown, such as 'Latham' raspberry, 'Trumpeter' strawberry, and 'Beacon' and 'Haralson' apples. The 'North Star' cherry, 'Sungold' and 'Moongold' apricots, 'Red Lake' currant, and several plum cultivars still are commonly planted in gardens in the northern United States and Canada.

The current fruit breeding program remains comprehensive, with substantial efforts in apple, wine and seedless grapes, blueberry, strawberry, and raspberry. The objective in breeding all these crops is to combine high levels of fruit quality with low-temperature tolerance or avoidance mechanisms. A major goal of the program always has been to develop new crops with commercial potential for the region. Consistent with this goal, major efforts in the past 20 years have been devoted to developing grape and blueberry cultivars with sufficient hardiness and quality to be cultivated commercially. The current strawberry breeding program is in cooperation with G.J. Galletta of the U.S. Dept. of Agriculture (USDA) and seeks to incorporate resistance to red stele root rot (Phytophthora fragariae Hickman) in cold-tolerant, high-quality cultivars. In the apple breeding program, selection emphasizes cold tolerance, high dessert quality, and resistance to firelight [Erwinia amylovora (Burr) Winslow et al.]. Enhancement of the primocane fruiting habit as a means of low-temperature avoidance is a major objective in red raspberry breeding (Hoover et al., 1988; Luby et al., 1987). In addition to breeding, we have acquired cultivars of these and other fruit crops from around the world to test them for adaptation in the region.

Selection for fruit quality in the breeding program is enhanced by using trained sensory panels to evaluate both fresh and processed fruit. These panels, under the direction of S.T. Munson, characterize and compare genotypes in advanced testing stages using a difference/descriptive score card (Heintz and Kader, 1983; Larmond, 1977). The information generated is used to characterize new cultivars and select parents for further crossing. 


\section{EVALUATION OF COLD HARDINESS}

Although knowledge of the physiology of cold hardiness has been advanced considerably in the past two decades, detecting consistent genetic differences in cold hardiness remains a difficult task (Quamme and Stushnoff, 1983). The difficulty stems, in part, from the complex nature of cold hardiness as a trait. Stushnoff (1972) listed seven components of acclimation and deacclimation to low temperature: a) time of development of cold tolerance, b) rate of development of cold tolerance, c) intensity of tolerance developed, d) retention of cold tolerance, e) onset of loss of tolerance, f) rate of loss of tolerance, and g) ability to regain tolerance. Because timing and intensity of low temperatures vary from year to year and among diverse locations within the region, plants are being selected for a target population of environments that encompasses virtually an infinite set of combinations of alternating temperatures during the fall-winter-spring seasons. Genotypes would be expected to vary for the seven components of acclimation and deacclimation described above, and this suggests that there should be considerable genotype-environment interaction for cold hardiness as a trait. Indeed, this is the case in studies in which a set of genotypes is repeatedly evaluated for low-temperature injury (Cain and Anderson, 1980; Fear et al., 1985).

The importance of genotype-environment interactions for cold tolerance was illustrated recently in our program. Following each of three winter seasons, Fear et al. (1985) scored 50 blueberry families from a partial diallel mating scheme for winter injury using a subjective rating scale similar to those used by many fruit breeders. Heritability estimates (family-mean basis) in individual years was fairly high, ranging from 0.45 to 0.78 . However, the years were diverse in amount of snow cover and temperature regime, and because of genotype-year interaction effects, the heritability estimate over combined years was 0.02 . The implications from these results are that identifying genotypes that perform well every year will be difficult and that testing must be performed in a large sample of the target population of environments. Conversely, if we characterize each test environment (either in the field or in the laboratory) so that we know which components of cold tolerance or avoidance we are selecting for in each test, selection can be effective for plant responses that minimized low-temperature injury in that test.

Cold hardiness of genotypes in the Univ. of Minnesota program is assessed using laboratory freezing tests and multiple-location field testing. Laboratory freezing tests are conducted in a manner similar to that described by Holubowicz et al. (1982). The most tender tissue of the plant (e.g., xylem for apple, fruit-producing buds for grapes and blueberries) is assayed for tissue browning following exposure to low temperatures in a controlled freezing chamber. Such tests are usually performed once or twice each winter during late December to early February to assess midwinter low-temperature tolerance. Ideally, the tests should be conducted several times from late fall through spring. However, shortages of personnel and plant tissue, especially in the early stages of evaluation in the breeding program, limit the number of tests performed. We find that laboratory freezing tests are most useful to confirm differences among genotypes observed in field test results over several environments.

"Test winter" conditions have always been critical to progress in selecting for cold tolerance (Quamme and Stushnoff, 1983; Stushnoff, 1972). During many years (or at one location in a given year), the temperature regime and snow cover result in no substantial injury or in severe injury to all genotypes. Ideally, the test winter should result in differential low-temperature injury among genotypes. Yet, each test winter can provide slightly different challenges to the acclimation and deacclimation capabilities of a plant. Therefore, exposure to as many different test winters as possible during the testing of a genotype will provide a more complete assessment of potential adaptation.

In Minnesota, extensive field testing is conducted at experiment stations throughout the state, as well as at sites of cooperating producers. Advanced testing (using cloned genotypes) is conducted at two to six locations in Minnesota, depending on the crop. At the main breeding station at Excelsior, we experience test winters once or twice in 5 years for our elite grape, strawberry, raspberry, and blueberry breeding material and perhaps only once in 10 years for apple. By testing at multiple locations, advanced selections usually experience one or more test winter situations each year. Propagating and testing at many sites require higher initial expenses than multiple-year observations at a single location. However, for the complex traits of cold hardiness, the greater discrimination ability or higher potential rate of gain from selection on a per-year basis (Hansche, 1983) makes selection based on multiple-location testing essential in long-lived perennial plants.

\section{THE ROLE OF GERMPLASM ACQUISITION AND EVALUATION}

Fruit breeders in cold climates usually have many high-quality fruit genotypes available to them, but, most often, these are insufficiently hardy. Conversely, most of the very hardy genotypes are of mediocre or low quality. Combining these types of germplasm followed by repeated selection has been the slow but effective method used thus far to develop high-quality, hardy genotypes.

Acquisition and identification of certain cold-hardy genotypes have been critical factors in the success of the Minnesota program from its initiation. For example, in the apple breeding program begun at the turn of the century, the cultivar Malinda played a pivotal role (Dorsey, 1919). 'Malinda', originated in Orange County, Vt., and imported to Minnesota about 1860, was recognized for its hardiness, although its quality was only mediocre. Some 3800 seedlings from open-pollinated 'Malinda' seeds were evaluated through the 1910s, including the severe winter of 1917-18 (Dorsey, 1919). The seed source was an orchard planted to, in addition to 'Malinda', several of the high-quality cultivars of the era. From this population, several cultivars were introduced directly, and 'Malinda' appears in the ancestry of many Univ. of Minnesota apple introductions to this day (Table 1).

Germplasm acquisition and evaluation are, perhaps, more systematic today than they were in the early part of this century. Case histories of our blueberry and grape programs illustrate the continued importance of identifying key genotypes and, particularly, the importance of collection and evaluation of wild germplasm.

\section{Blueberry breeding in Minnesota and a history of "half-high" cultivar development}

Blueberries have been grown at research stations in Minnesota from time to time since the 1910s (Brierley and Hildreth, 1928; Brierley and Kenety, 1920). Highbush blueberry (Vacciniurn corymbosum L.) cultivars were often injured by low temperatures in late fall (Brierley and Hildreth, 1928; Quamme et al., 1972). Although research was conducted on propagation and cultivation of the native lowbush blueberries ( $V$. angustifolium Ait. and $V$. myrtilloides Michx.) (Brierley and Kenety, 1920), these were never grown commercially. A blueberry breeding program was initiated at the Univ. of Minnesota in 1967 by Stushnoff to develop coldhardy, low-statured ("half-high"), high-quality, large-fruited cultivars (Stushnoff, 1976). The first cultivars released from this effort, 'Northblue', 'Northsky, and 'Northcountry' (Luby et al., 1986), avoid low-temperature injury by their cold-tolerant inflorescence buds and low stature that allows part of the bearing surface to be covered by snow.

The concept of low-statured, large-fruited blueberries was advanced decades ago, and the Minnesota program took advantage of previous efforts in other states and combined several wild germplasm sources of cold tolerance: Michigan Lowbush 1 from the Michigan and USDA breeding programs, 'Ashworth' from F.L. Ashworth and the USDA program, V. angustifolium genotypes from Minnesota, and natural half-high genotypes from the eastern United States.

The task of developing a low-statured blueberry for northern regions was not mentioned in F.V. Coville's earliest publications (Coville, 1910). He clearly had conceived of it, however, because Brierley and Kenety (1920) reported receiving V. corymbosum $\times V$. angustifolium seedlings from him in 1916 for evaluation in Minnesota. The fate of these seedlings is unknown, as they apparently 
Table 1. Fruit cultivars introduced by the Univ. of Minnesota (1908-88).

\begin{tabular}{|c|c|c|c|}
\hline Cultivar & Minnesota no. & Year introduced & Parentage $^{z}$ \\
\hline \multicolumn{4}{|c|}{ Apples (Malus domestica Borkh.) } \\
\hline Minnehaha & 300 & 1920 & Malinda op \\
\hline Folwell & 237 & 1922 & Malinda op \\
\hline Wedge & 207 & 1922 & Probably Ben Davis op \\
\hline Haralson & 90 & 1923 & Malinda op \\
\hline Beacon & 423 & 1936 & Malinda op \\
\hline Prairie Spy & 1007 & 1940 & Unknown \\
\hline Minjon & 700 & 1942 & Unknown (possibly Jonathan $x$ Wealthy) \\
\hline Victory & 396 & 1943 & McIntosh op \\
\hline Fireside & 993 & 1943 & Unknown \\
\hline Redwell & 638 & 1946 & Scotts Winter op \\
\hline Oriole & 714 & 1949 & Unknown \\
\hline Lakeland & 978 & 1950 & Malinda op \\
\hline Regent & 1430 & 1964 & Daniel's Red Duchess $\times$ Delicious \\
\hline Honeygold & 1595 & 1969 & Golden Delicious $\times$ Haralson \\
\hline Red Baron & 1500 & 1969 & Golden Delicious × Daniel's Red Duchess \\
\hline State Fair & 1639 & 1978 & Mantet $x$ Oriole \\
\hline Sweet Sixteen & 1630 & 1978 & MN 447 (Malinda op) $\times$ Northern Spy \\
\hline Keepsake & 1593 & 1979 & MN 447 (Malinda op) $\times$ Northern Spy \\
\hline Honeycrisp & 1711 & 1990 & Macoun $x$ Honeygold \\
\hline \multicolumn{4}{|c|}{ Apricots (Prunus armeniaca L.) } \\
\hline Moongold & 15 & 1960 & Superb $\times$ Manchu \\
\hline Sungold & 36 & 1960 & Superb $\times$ Manchu \\
\hline \multicolumn{4}{|c|}{ Blueberries (Vaccinium spp. L.) } \\
\hline Northblue & 360 & 1983 & $\mathrm{~B} 10 \times \mathrm{US3}^{\mathrm{y}}$ \\
\hline Northsky & 332 & 1983 & $\mathrm{~B} 6 \times \mathrm{R} 2 \mathrm{P} 4 \mathrm{y}$ \\
\hline Northcountry & 350 & 1986 & $\mathrm{~B} 6 \times \mathrm{R} 2 \mathrm{P} 4 \mathrm{y}$ \\
\hline \multicolumn{4}{|c|}{ Nanking cherries (Prunus tomentosa Thunb.) } \\
\hline Orient & 63 & 1949 & Seedling from self-fertile Nanking cherry \\
\hline \multicolumn{4}{|c|}{ Sour cherries (Prunus cerasus L.) } \\
\hline Northstar & 58 & 1950 & English Morello x Serbian Pie 1 \\
\hline Meteor & 66 & 1952 & Montmorency $\times$ Vladimir \\
\hline \multicolumn{4}{|c|}{ Cherry-plums ${ }^{\mathbf{x}}$ (Prunus spp.) } \\
\hline Zumbra & -- & 1920 & $\begin{array}{l}\text { (Prunus avium L. } \times \text { P. pennsylvanica L.) } \times P \text {. bes- } \\
\text { seyi Bailey }\end{array}$ \\
\hline St. Anthony & 145 & 1923 & $P$. besseyi $\times$ Satsuma plum \\
\hline Nicollet & 144 & 1925 & $(P$. avium $\times P$. pennsylvanica) $\times P$. besseyi \\
\hline Deep Purple & 440 & 1965 & Sioux $(P$. besseyi $) \times$ Elephant Heart plum \\
\hline \multicolumn{4}{|c|}{ Crabapples (Malus spp.) } \\
\hline Flame & 635 & 1934 & Unknown \\
\hline Chestnut & 240 & 1946 & Malinda op \\
\hline Northland & 1423 & 1957 & McIntosh $\times$ Dolgo \\
\hline Centennial & 1472 & 1957 & Dolgo $x$ Wealthy \\
\hline \multicolumn{4}{|c|}{ Currants (Ribes rubrum L.) } \\
\hline Red Lake & 24 & 1933 & Unknown \\
\hline Cascade & 70 & 1942 & Diploma op \\
\hline \multicolumn{4}{|c|}{ Gooseberries (Ribes spp.) } \\
\hline Como & 43 & 1922 & Pearl $\times$ Columbus \\
\hline Welcome & 206 & 1957 & Poorman op \\
\hline \multicolumn{4}{|c|}{ Grapes (Vitis spp.) } \\
\hline Red Amber & 45 & 1944 & Unknown \\
\hline Moonbeam & 66 & 1944 & Unknown \\
\hline Blue Jay & 69 & 1944 & Unknown \\
\hline Bluebell & 158 & 1944 & Unknown \\
\hline Swenson Red & E.S. 439 & 1978 & MN $78 \times$ Seibel 11803 \\
\hline Edelwiess & E.S. 40 & 1978 & MN $78 \times$ Ontario \\
\hline \multicolumn{4}{|c|}{ Peach-almond $\mathbf{x}$ (Prunus spp.) } \\
\hline Manitou & 7 & 1923 & $P$. nana Stokes $\times$ Bokara peach \\
\hline \multicolumn{4}{|c|}{ Pears (Pyrus spp.) } \\
\hline Parker & 1 & 1934 & Seed received from Manchuria \\
\hline Bantam & 3 & 1940 & Unknown \\
\hline Golden Spice & 4 & 1949 & Unknown \\
\hline Summercrisp & N33201 & 1987 & Unknown \\
\hline & & Plums $\mathbf{x}$ (Prunu & IS $s p p)$. \\
\hline Elliot & 8 & 1920 & Probably Apple $\times P$. americana Marsh \\
\hline Monitor & 70 & 1920 & Burbank $\times P$. americana \\
\hline Red Wing & 12 & 1920 & Burbank $x$ Wolf \\
\hline Tonka & 21 & 1920 & Burbank $\times$ Wolf \\
\hline Underwood & 91 & 1920 & Shiro $\times$ Wyant \\
\hline Anoka & 118 & 1922 & Burbank $\times$ De Soto \\
\hline Mound & 50 & 1922 & Burbank $\times$ Wolf \\
\hline
\end{tabular}

(continued) 
Table 1. continued.

\begin{tabular}{|c|c|c|c|}
\hline Cultivar & Minnesota no. & Year introduced & Parentage ${ }^{2}$ \\
\hline Winona & 30 & 1922 & Abundance $\times$ Wolf \\
\hline Goldenrod & 120 & 1923 & Shiro $\times$ Howard Yellow \\
\hline Hennepin & 132 & 1923 & Satsuma $\times P$. americana \\
\hline La Crescent & 109 & 1923 & Shiro $\times$ Howard Yellow \\
\hline Waconia & 10 & 1923 & Burbank $\times$ Wolf \\
\hline Newport & 116 & 1923 & Omaha $x$ Pissardi \\
\hline Mendota & 5 & 1924 & Burbank $\times$ Wolf \\
\hline Radisson & 157 & 1925 & $P$. salicina $\times P$. americana \\
\hline Superior & 194 & 1933 & Burbank x Kaga \\
\hline Ember & 83 & 1936 & Shiro $\times$ S.D. 33 (P. americana) \\
\hline Redcoat & 17 & 1942 & Burbank $\times$ Wolf \\
\hline Pipestone & 218 & 1942 & Burbank $\times$ (Burbank $\times$ Wolf) \\
\hline Redglow & 101 & 1949 & Burbank x Jewell \\
\hline South Dakota & S.Dak. 27 & 1949 & Unknown (origin South Dakota Agr. Expt. Sta.) \\
\hline Alderman & 416 & 1986 & Burbank x Older \\
\hline \multicolumn{4}{|c|}{ Red raspberries (Rubus idacus $L$. ) } \\
\hline Latham & 4 & 1920 & King $\times$ Louden \\
\hline Chief & 223 & 1930 & Latham selfed \\
\hline Itasca & 399 & 1965 & Newburgh selfed \\
\hline Redwing & 629 & 1986 & Heritage $x$ Fallred \\
\hline Nordic & 603 & 1987 & Boyne $\times$ Fallred \\
\hline \multicolumn{4}{|c|}{ Strawberries (June bearing) (Fragaria $\times$ ananassa Duch.) } \\
\hline Minnehaha & 935 & 1920 & Minnesota $\times$ Abington \\
\hline Minnesota & 3 & 1920 & Dunlap $\times$ Pocomoke \\
\hline Chaska & 801 & 1922 & (Dunlap $\times$ Pocomoke) $\times$ Brandywine \\
\hline Easypicker & 775 & 1922 & Crescent $\times$ Dunlap \\
\hline Nokomis & 489 & 1922 & Dunlap $\times$ Abington \\
\hline Burgundy & 1192 & 1943 & Easypicker $\times$ Duluth \\
\hline Arrowhead & 1118 & 1946 & Duluth $\times$ Dunlap \\
\hline Earlimore & 1636 & 1958 & (Campbell $\left.\mathrm{S}_{1}\right) \times$ Howard 17 \\
\hline Trumpeter & $\cdots$ & 1960 & Burgundy $\times$ (Howard $17 \mathrm{~S}_{1}$ ) \\
\hline Northland & 1868 & 1982 & Burgundy $\times$ Premier \\
\hline \multicolumn{4}{|c|}{ Strawberries (everbearing) (Fragaria $\times$ ananassa Duch.) } \\
\hline Duluth & 1017 & 1920 & Pan American $x$ Dunlap \\
\hline Deephaven & 41 & 1922 & Unknown \\
\hline Evermore & 1166 & 1945 & Duluth $\times$ Dunlap \\
\hline
\end{tabular}

op = Open-pollinated.

${ }^{y}$ See Luby et al. (1986) for complete ancestry.

'See Anderson and Weir (1967) for further information on ancestry.

never entered the modern university breeding program. Coville actually made $V$. corymbosum $\times V$. angustifolium crosses as early as 1913 and introduced the half-high cultivar Greenfield that was never established commercially (Coville, 1937).

Stanley Johnston realized in 1926 that highbush $\times$ lowbush plants might provide a new crop for northern areas of Michigan (Johnston, 1956). He spent Summer 1926 to 1930 exploring northern Michigan for superior lowbush genotypes. These were crossed with highbush genotypes, and, although most of the resulting seedlings produced disappointingly small and dark fruit (Johnston, 1946), the progeny of one selection, designated Michigan Lowbush 1, were somewhat taller and had lighter-colored fruit than the others. Darrow et al. (1952) suspected that Michigan Lowbush 1 was a $V$. angustifolium $\times$ tetraploid $V$. myrtilloides derivative because of its "robust" plant habit, pubescent leaves, and frosty blue fruit.

Michigan Lowbush 1 appears as an ancestor of the cultivars Northland, Bluehaven, and Tophat from Johnston's Michigan program (Draper, 1979; Johnston and Moulton, 1967; Moulton et al., 1977). The USDA continued to work with highbush $\times$ lowbush crosses involving Johnston's lowbush selections (Darrow et al., 1952, 1960), eventually producing several selections, including one designated US-3 ('Dixi' $\times$ Michigan Lowbush 1), which is a parent of 'Patriot' from the Maine-USDA program (Hepler and Draper, 1976) and 'Northblue' from the Minnesota program. In Minnesota, 'Northland' and 'Patriot', along with 'Bluetta', exhibit the least low-temperature injury of the highbush cultivars (Quamme et al., 1972; Quamme, unpublished data). Michigan Lowbush 1 likely contributed this hardiness.

In New Hampshire, an attempt to develop stoloniferous half-high plants with light-blue fruit was initiated in the 1940s (Meader et al., 1954). Native New Hampshire V. angustifolium clones were crossed with highbush cultivars. A preponderance of very low-statured and dark-fruited plants led Meader et al. to conclude that "this plant breeding project still offers a challenge" and that large progenies would have to be grown to realize its objectives. No half-high cultivars were introduced from this program.

As the USDA blueberry breeding program expanded to develop highbush cultivars for the northeastern and midwestem United States, the limitations of Coville's initial wild selections from southern New Hampshire and New Jersey for cold hardiness became apparent and an effort was made to select hardier types at cooperator sites in Michigan and Maine (Darrow et al., 1960). G.M. Darrow, of the USDA, began working with a cooperator, F.L. Ashworth of the St. Lawrence River valley of northern New York, who had collected several wild $V$. corymbosum plants from the local area. The St. Lawrence valley is near the northern limit of the range of $V$. corymbosum. One of the clones collected by Ashworth, and named after him, produced many hardy progeny in crosses with highbush cultivars and selections (Darrow et al., 1960).

In 1965, seeds from several crosses of the 'Ashworth' clone with highbush genotypes were received in Minnesota from USDA breeders D.H. Scott and A.D. Draper. Some 24 large-fruited and very hardy selections were made from the cross 'Ashworth' $\times \mathrm{G} 65$. These selections appear in the ancestry of most Minnesota breeding material. Hardiness of the 'Ashworth'-derived material has been confirmed by our observations in Minnesota (Fear et al., 1985).

Other germplasm used as sources of cold hardiness has included V. angustifolium genotypes from Minnesota (Fear et al., 1985; Quamme et al., 1972) and natural half-high populations collected at the Harvard Forest in Massachusetts and evaluated at Grand Rapids in northern Minnesota (Fear et al., 1985; Luby et al., 1986; Quamme et al., 1972). Several researchers (Darrow et al., 1952; 
Johnston, 1946, 1956; Meader et al., 1954) reported difficulty in obtaining half-high genotypes of desired stature and fruit characteristics in early generations of $V$. corymbosum $\times V$. angustifolium crosses. However, we have observed considerable segregation for plant stature, bloom and ripening dates, ripening uniformity, fruit size, color, picking scar, and firmness in advanced generations (Finn and Luby, 1986a, 1986b; Luby and Finn, 1986, 1987). The current objective in the Univ. of Minnesota program is to improve fruit quality while maintaining levels of cold hardiness. We also continue to search for new sources of cold hardiness in recent collections of $V$. angustifolium from Minnesota, Wisconsin, Michigan, New York, and New Hampshire, and in collections of V. corymbosum from the northern limits of its range in Michigan and New York.

Recently, we have begun breeding for another low-temperature injury avoidance strategy in the Minnesota blueberry program. Flowering on current season's growth ("off-season flowering") has been reported in V. angustifolium (Galletta, 1975; Vander Kloet, 1978) and is apparently a response to photoperiod and temperature (Hall and Ludwig, 1961; Luby, unpublished data). As with primocane-fruiting raspberry (Keep, 1988), off-season flowering results in fruit being produced in the late summer and early autumn. Fear (1983) found considerable variation for this trait among $V$. angustifolium collected from Minnesota, Wisconsin, and Manitoba, Canada, and found that it was heritable in half-high progenies (Fear et al., 1985), suggesting that continued selection should enhance expression of the trait.

\section{Grape breeding in Minnesota}

The history of grape breeding in Minnesota provides another example of breeding programs building upon one another's germplasm and, particularly, the key role of wild germplasm of the species Vitis riparia Michx.

Early settlers in Minnesota discovered that the V. labrusca L.type cultivars they brought from the eastern United States were often injured in the winter or failed to ripen before killing autumn frosts. A German immigrant, Louis P. Suelter of Carver, Minn., was among the first of many local breeders. He crossed a rare white-fruited $V$. riparia clone with 'Concord' and introduced the cultivars Beta, Suelter, Monitor, and Dakota from this cross (Swenson, 1985). 'Beta' became an important cultivar in Minnesota, with some 100 ha in the Minneapolis-St. Paul area until the 1930s, and it remains popular today with regional gardeners.

'Beta' also became the basis of further breeding work in Minnesota. M.J. Dorsey initiated the Univ. of Minnesota's grape breeding program in 1908, crossing 'Beta' with various labrusca -type cultivars, including 'Concord', 'Delaware', 'Witt', 'Agawam', 'Salem', and others (Wilcox, 1946). Four cultivars were introduced from this work: 'Moonbeam', 'Red Amber', 'Blue Jay', and 'Bluebell', although only 'Bluebell' is currently propagated. The breeding program for labrusca-type juice and jelly grapes was continued on a small scale through the 1940s by Wilcox (1946), but no further introductions were made, although several of the selections have been used in E.P. Swenson's breeding program (Swenson, 1985).

An unnamed distillate selection from Dorsey's work made the most important contribution to further grape breeding in the region. MN 78 ('Beta' $\times$ 'Witt'), a purple, sweet, and very hardy grape, was used extensively in Swenson's breeding program, which began in the 1940s. Swenson used a variety of early ripening, high-quality labrusca-type cultivars and also was the first to incorporate FrenchAmerican hybrids into Midwestern grape breeding. MN 78 was the female parent of Swenson's first table grape introductions, 'Edelweiss' and 'Swenson Red' (Swenson et al., 1978), and is also in the parentage of his more recent introductions 'Kay Gray', 'St. Croix', 'LaCrosse', 'St. Pepin', and 'Esprit'. Swenson used several different $V$. riparia sources in his program, including several from eastern Minnesota and western Wisconsin and others from Montana, North Dakota, and South Dakota through his use of N.E. Hansen's cultivars developed at South Dakota State Univ. (Swenson, 1985).

Grape breeding at the Univ. of Minnesota was revived by P. Pierquet, C. Stushnoff, and E. Swenson in the mid-1970s. Pierquet and Stushnoff (1978) evaluated fruit from V. riparia genotypes collected in central Minnesota and in the Riding Mountains of Manitoba and documented considerable variation for ripening date, cluster size, percent soluble solids content, titratable acidity, and juice $\mathrm{pH}$. We also have observed variation in this material for pigment and flavor intensity (Hemstad and Luby, unpublished data). The best of these selections have formed the foundation for breeding for increased hardiness in the university program and in Swenson's program (Swenson, 1985).

Pierquet and Stushnoff (1978) also emphasized that some unique characteristics of the Manitoba genotypes may have contributed to their ability to survive at the northern limit of the range of $V$. riparia. They noted that these genotypes ripened their fruit very early and were from an area with an average growing season of $\approx 110$ frost-free days. They speculated that this germplasm may contain a photoperiodic response for growth cessation and cold acclimation. Research conducted with 'Concord' (Wolpert and Howell, 1986) and 'White Riesling' (Schnabel and Wample, 1987) indicated little or no acclimation response to photoperiod changes, in contrast to results with other woody species (Nitsch, 1957; VincePrue, 1975). Recently, Fennell and Hoover (1987) demonstrated that one of the Manitoba $V$. riparia genotypes did indeed become dormant and acclimate in response to decreasing photoperiods. Conrod (1988) showed that the dormancy response was heritable in progenies of a Manitoba $V$. riparia and could be induced in 10week-old seedlings, and developed acclimation regimes that may be useful for juvenile selection or-progeny testing of parents for this trait.

The present Univ. of Minnesota program depends on several germplasm sources for hardiness, including Minnesota and Manitoba $V$. riparia genotypes and cultivars with $V$. riparia ancestry from both the Swenson and South Dakota breeding programs (Peterson, 1963; Peterson et al., 1988), as well as others. Other potential germplasm sources for cold hardiness that are currently being evaluated include $V$. riparia, $V$. longii, and $V$. vulpina populations form North America, and $V$. amurensis and $V$. vinifera $\times V$. amurensis derivatives from Asia and Europe. In addition, populations are being developed that have both $V$. riparia and $V$. amurensis as sources of hardiness. Genes for high wine quality are being incorporated from $V$. vinifera and French hybrid cultivars, while seedless table grapes are being developed primarily from cultivars that originated in the eastern United States and Canada.

\section{THE FUTURE}

The prospects for continued development of cold-hardy, highquality fruit cultivars in Minnesota using conventional breeding techniques are encouraging because of the foundation of germplasm collected and developed through the history of the program. To politically ensure its future in an era that has seen the discontinuation of several fruit breeding programs in the region, the Univ. of Minnesota program, like all others, will need the continued support of fruit producers, nursery operators, and others who depend on the introduction of new fruit cultivars.

The establishment of a vigorous germplasm collection program and clonal germplasm repositories for fruit crops in the United States should allow ready access to germplasm from around the world. The repositories were established at sites where most of the collections were unlikely to be injured by low temperatures. While this ensures survival of the collections, it also disallows efficient evaluation for cold hardiness in the field. Some type of laboratory freezing test regime and/or cooperative field evaluation program at colder sites will be necessary to determine the potential of this germplasm.

Finally, we will see plant transformation and molecular genetic techniques supplement conventional fruit crop improvement programs in the next two decades. These techniques offer the potential to engineer the genome more precisely and, possibly, to shorten the time for fruit crop improvement. The recent successful attempts at in vitro regeneration of deciduous fruit crops from somatic tissue will allow the application of plant transformation technology to introduce specific, simply inherited characters to established cultivars. For traits usually considered polygenic, restriction fragment length maps may allow juvenile selection for linked genes. These 
technologies already are used in some annual crops but have even greater potential to increase breeding efficiency in long life-cycle fruit crops.

\section{Literature Cited}

Alderman, W.H. 1976. Development of fruit growing in the American states and Canadian provinces-Minnesota, p. 82-85. In: D.V. Fisher and W.H. Upshall (eds.). History of fruit growing and handling in United States of America and Canada. Regatta City Press, Kelowna, B. C., Canada.

Anderson, E.T. and T.S. Weir. 1967. Prunus hybrids, selections and cultivars, at the University of Minnesota Fruit Breeding Farm. Univ. of Minnesota Agr. Expt. Sta. Tech. Bul. 252.

Brierley, W.G. and A.C. Hildreth. 1928. Some studies on the hardiness of certain species of Vaccinium. Plant Physiol. 3:303-308.

Brierley, W.G. and W.H. Kenety. 1920. Blueberry culture in MinnesotaA report of progress. Proc. Amer. Soc. Hort. Sci. 17:243-249.

Cain, D.W. and R.L. Anderson. 1980. Inheritance of wood hardiness among hybrids of commercial and wild Asian peach genotypes. J. Amer. Soc. Hort. Sci. 105:349-354.

Conrod, J.D. 1988. Acclimation and dormancy responses of Vitis seedlings to photoperiod and temperature. MS Thesis, Univ. of Minnesota, St. Paul.

Coville, F.V. 1910. Experiments in blueberry culture. U.S. Dept. Agr. Bur. Plant Ind. Bul. 193.

Coville, F.V. 1937. Improving the wild blueberry. U.S. Dept. Agr. Yrbk. Agr. p. 559-574.

Darrow, G. M., E.B. Morrow, and D.H. Scott. 1952. An evaluation of interspecific blueberry crosses. Proc. Amer. Soc. Hort. Sci. 59:277-282.

Darrow, G. M., L. Whitton, and D.H. Scott. 1960. The Ashworth blueberry as a parent in breeding for hardiness and earliness. Fruit Var. Hort. Dig. 14:43-46.

Dorsey, M.J. 1919. Some characteristics of open-pollinated seedlings of the Malinda apple. Proc. Amer. Soc. Hort. Sci. 16:36-42.

Draper, A.D. 1979. Highbush blueberry cultivars. Fruit Var. J. 33:48-50.

Fear, C.D. 1983. Investigation of off-season flowering in lowbush and halfhigh blueberries. PhD Diss., Univ. of Minnesota, St. Paul.

Fear, C. D., F.I. Lauer, J.J. Luby, R.L. Stucker, and C. Stushnoff. 1985 Genetic components of variance for winter injury, fall growth cessation, and off-season flowering in blueberry progenies. J. Amer. Soc. Hort. Sci. 110:262-266.

Fennell, A.E. and E.E. Hoover. 1987. Influence of photoperiod on cold acclimation in V. riparia Michx. HortScience 22:1088. (Abstr.)

Finn, C.E. and J.J. Luby. 1986a. Inheritance of fruit development interval and fruit size in blueberry progenies. J. Amer. Soc. Hort. Sci. 111:784788 .

Finn, C.E. and J.J. Luby. 1986b. Inheritance of fruit color, scar, and firmness in Vuccinium. HortScience 21:767. (Abstr.)

Galletta, G.J. 1975. Blueberries and cranberries, p. 154-196. In: J. Janick and J.N. Moore (eds.). Advances in fruit breeding. Purdue Univ. Press, West Lafayette, Ind.

Hall, I.V. and R.A. Ludwig. 1961. The effects of photoperiod, temperature, and light intensity on the growth of the lowbush blueberry (Vaccinium angustifolium Ait. ). Can. J. Bet. 39:1733-1739.

Hansche, P.E. 1983. Response to selection, p. 154-171. In: J.N. Moore and J. Janick (eds.). Methods in fruit breeding. Purdue Univ. Press, West Lafayette, Ind.

Heintz, C.M. and A.A. Kader. 1983. Procedures for the sensory evaluation of horticultural crops. HortScience 18: 18-22.

Hepler, P.R. and A.D. Draper. 1976. Patriot blueberry. HortScience 11:272.

Holubowicz, T., J.N. Cummins, and P.L. Forsline. 1982. Responses of Malus clones to programmed low-temperature stresses in late winter. J. Amer. Soc. Hort. Sci. 107:492-496.

Hoover, E. E., J.J. Luby, D.S. Bedford, and M.P. Pritts. 1988. Reproductive yield components of primocane-fruiting red raspberries. J. Amer. Soc. Hort. Sci. 113:824-826.
Keep, E. 1988. Primocane (autumn) -fruiting raspberries: A review with particular reference to progress in breeding. J. Hort. Sci. 63:1-18.

Johnston, S. 1946. Observations on hybridizing lowbush and highbush blueberries. Proc. Amer. Soc. Hort. Sci. 47:199-200.

Johnston, S. 1956. Blueberry breeding in Michigan. Fruit Var. Hort. Dig. 11:20.

Johnston, S. and J.E. Moulton. 1967. The Bluehaven and Northland blueberry varieties. Quart. Bul. Michigan Agr. Expt. Sta. 50(1):46-49.

Larmond, E. 1977. Laboratory methods for sensory evaluation of food. Calif. Dept. Agr. Publ. 1637.

Luby, J.J. and C.E. Finn. 1986. Quantitative inheritance of plant growth habit in blueberry. J. Amer. Soc. Hort. Sci. 111:609-611.

Luby, J.J. and C.E. Finn. 1987. Inheritance of ripening uniformity in relationship to crop load in blueberry. J. Amer. Soc. Hort. Sci. 112:167170.

Luby, J. J., E.E. Hoover, D.S. Bedford, S.T. Munson, W.H. Gray, D.K. Wildung, and C. Stushnoff. 1987. 'Redwing' raspberry. HortScience 22:681-682.

Luby, J.J., D.K. Wildung, C. Stushnoff, S.T. Munson, P.E. Read, and E-E. Hoover. 1986. 'Northblue', 'Northsky', and 'Northcountry' blueberries. HortScience 21:1240-1242.

Meader, E. M., W.W. Smith, and A.F. Yeager. 1954. Bush types and fruit colors in hybrids of highbush and lowbush blueberries. Proc. Amer. Soc. Hort. Sci. 63:272-278.

Moulton, J. E., S. Johnston, and R.L. Andersen. 1977. Tophat blueberry. HortScience 12:509.

Nitsch, J.P. 1957. Photoperiodism in woody plants. Proc. Amer. Soc. Hort. Sci. 70:526-527.

Peterson, R.M. 1963. Breeding grapes for the northern Great Plains. Fruit Var. J. 17:67-68.

Peterson, R. M., J.R. Waples, and N.P. Evers. 1988. 'Valiant' grape. HortScience 23:417.

Pierquet, P. and C. Stushnoff. 1978. Variation and breeding potential of some northern clones of Vitis riparia Michx. Fruit Var. J. 32:74-84.

Quamme, H.A. and C. Stushnoff. 1983. Resistance to environmental stress, p. 242-266. In: J.N. Moore and J. Janick (eds.). Methods in fruit breeding. Purdue Univ. Press, West Lafayette, Ind.

Quamme, H. A., C. Stushnoff, and C.J. Weiser. 1972. Winter hardiness of several blueberry species and cultivars in Minnesota. HortScience 7:500502.

Schnabel, B.J. and R.L. Wample. 1987. Dormancy and cold hardiness of Vitis vinifera L. cv. 'White Riesling' as influenced by photoperiod and temperature. Amer. J. Enol. Vitic. 38:265-272.

Snyder, L.C. 1983. History of the Department of Horticultural Science and Landscape Architecture. Univ. of Minnesota, St. Paul.

Stushnoff, C. 1972. Breeding and selection methods for cold hardiness in deciduous fruit crops. HortScience 7:10-13.

Stushnoff, C. 1976. Development of cold hardy blueberry hybrids. Fruit Var. J. 30:28-29.

Swenson, E.P. 1985. Wild Vitis riparia from northern U.S. and Canadabreeding source for winter hardiness in cultivated grapes-A background of the Swenson hybrids. Fruit Var. J. 39:28-31.

Swenson, E. P., P. Pierquet, and C. Stushnoff. 1978. 'Edelweiss' and 'Swenson Red' grapes. HortScience 15:100.

Vander Kloet, S.P. 1978. Systematic, distribution, and nomenclature of the polymorphic Vaccinium angustifolium. Rhodora 80:358-376.

Vince-Prue, D. 1975. Stem elongation and dormancy, p. 333-384. In: Photoperiodism in plants. McGraw Hill, New York.

Wilcox, A.N. 1946. Grape breeding at the Minnesota station. Fruit Var. Hort. Dig. 1:31-34.

Wolpert, J.A. and G.S. Howell. 1986. Effect of night interruption on cold acclimation of potted 'concord' grapevines. J. Amer. Soc. Hort. Sci. 111:16-20. 